\title{
Raimonda Ragauskiené
}

Instytut Historii Litwy, Wilno

\section{Kiedy poglądy religijne stają się nieważne: medycy protestantów Mikołaja Radziwiłła "Czarnego" (1515-1565) i Radziwiłłów na Birżach i Dubinkach}

\begin{abstract}
Zarys treści
$\mathrm{W}$ artykule przedstawiono grupę lekarzy służących najwybitniejszym protestantom w Wielkim Księstwie Litewskim - księciu na Ołyce i Nieświeżu, wojewodzie wileńskiemu Mikołajowi Radziwiłłowi „Czarnemu” oraz linii Radziwiłłów na Birżach i Dubinkach. Analizy ukazały, że wszyscy medycy leczący przedstawicieli tego najznaczniejszego rodu litewskiego byli specjalistami o najwyższych kwalifikacjach. Duży wpływ na wybieranie przez Radziwiłłów lekarzy spośród protestantów miała ukształtowana tradycja zatrudniania fachowych medyków, system protekcji oraz model rodzinny (niemała liczba małżeństw mieszanych pod względem wyznania).
\end{abstract}

\begin{abstract}
The article focuses on the group of physicians, who served as family doctors of the most prominent protestants of the Grand Duchy of Lithuania: Prince of Olyka and Nesvizh, Voivode of Vilnius Mikołaj the Black Radziwiłł, and the Biržai-Dubingiai line of the Radziwiłł family. All physicians treating the members of the Protestant Radziwiłł family were professionals of the highest caliber. The article concludes that both the tradition of employing professional physicians, the system of protection, and especially the family model (a considerable number of mixed marriages in terms of religion) had a great impact on the selection of the Protestant physicians of the Radziwiłłs.
\end{abstract}

Słowa kluczowe: Mikołaj Radziwiłł Czarny, Radziwiłłowie na Birżach i Dubinkach, protestanci, Wielkie Księstwo Litewskie, grupa lekarzy protestantów

Keywords: Mikołaj the Black Radziwiłł, the Biržai and Dubingiai line of the Radziwiłł family, Protestants, Grand Duchy of Lithuania, group of Protestant physicians

Reformacja wpłynęła na wiele dziedzin życia społecznego. W historiografii w największym stopniu analizowany jest wpływ ruchu reformacyjnego na sprawy duchowe, podkreśla się też jego rolę w dziedzinie kultury i oświaty, jako nurtu 
sprzyjającego modernizacji kultury ${ }^{1}$. Mniej natomiast uwagi zwracano na zmiany zachodzące $\mathrm{w}$ praktycznych sferach życia rodzinnego, na płaszczyźnie zdrowotnej i medycznej, na które również miała wpływ reformacja ${ }^{2}$. Wymienię tylko kilka $\mathrm{z}$ tych obszarów, na które reformacja także oddziaływała, a były one nie mniej ważne.

W krajach protestanckich przede wszystkim na nowo przewartościowano stosunek do celibatu i małżeństwa, na temat którego protestanci wypowiedzieli szczególnie dużo pochwalnych słów ${ }^{3}$. Wprowadzony przez Jana Kalwina wymóg, by przy zawieraniu związku małżeńskiego otrzymać zgodę rodziców, było jedną z ważniejszych zrealizowanych w XVI w. reform, mającą przyczynić się do wyeliminowania tolerowanych dotychczas nieformalnych związków ${ }^{4}$. Zalegalizowany związek pomiędzy krewnymi stał się jawnym znakiem czasu pierwszych protestantów, szczególnie w Anglii ${ }^{5}$. Ponadto w społeczeństwach przedindustrialnych liczbę narodzin jako pierwsi zaczęli regulować właśnie protestanci, np. klasa średnia w Szwajcarii, co związane było z etyką protestancką, chęcią troski o dzieci, o zabezpieczenie ich sytuacji. Lecz szerzej takie zachowania zaczęto praktykować w drugiej połowie XVII w. ${ }^{6}$

Rozpowszechnienie idei protestantyzmu oraz stawiane przez epokę renesansu wymagania krytycznego studiowania spuścizny antycznej medycyny, a także odrzucenie teorii humoralnej stopniowo zmieniały tradycyjny model medycyny galenowej ${ }^{7}$. Bardziej charakterystyczne dla efektywnej medycyny europejskiej

${ }^{1}$ D. Karvelis, Religijos tolerancija Lietuvos Didžiosios Kunigaikštystès tikejjimo disputu epochoje XVI-XVII a., w: Disputai: idejos, vizijos. Skiriama Reformacijos 500 metu jubiliejui, red. A. Arlauskienė, A. Prašmantaite, Vilnius 2017, s. 3-8.

${ }^{2}$ Więcej o tym zob. A. Saar-Kozłowska, Lekarz miejski Leszna Jan Jonston i kora chinowca - między religia, tradycją a medycyną, w: Reformacja i tolerancja. Jedność w różnorodności? Wspótistnienie rożnych wyznań na ziemi wschowskiej i pograniczu wielkopolsko-śląskim, red. M. Małkus, K. Szymańska, Wschowa-Leszno 2015, s. 364.

${ }^{3}$ M. Bogucka, Polski renesans a rodzina. Poglądy Mikołaja Reja na małżeństwo i rodzinę, w: Spoteczeństwo staropolskie. Seria nowa, t. 3: Społeczeństwo a rodzina, red. I.M. Dacka-Gorzyńska, A. Karpiński, Warszawa 2009, s. 16-20.

${ }^{4}$ J. Witte, Clandestine Marriage and Parental Consent in John Calvin's Geneva, w: Law and Marriage in Medieval and Early Modern Times, red. P. Andersen, K. Salonen, H. Moller Sigh, H. Vogt, Copenhagen 2012, s. 273-274.

5 B. Wiebracht, First-cousin Marriage in Tudor and Stuart England: 1540-1688, „Journal of Family History" 40, 2015, nr 1, s. 24-38.

${ }^{6}$ R. Jütte, Contraception. A History, Cambridge 2008, s. 61.

7 C.B. Schmitt, Aristotle among the Physicians, w: The Medical Renaissance of the Sixteenth Century, red. A. Wear, R.K. French, I.M. Lonie, Cambridge 1985, s. 9-11; N.G. Siraisi, Medieval and Renaissance Medicine: Continuity and Diversity, „Journal of History of Medicine and Allied Sciences” 41, 1986, nr 4, s. 391-394; I. Maclean, Logic, Signs and Nature in the Renaissance. The Case of Learned Medicine, Cambridge 2002, s. 14-15; S.K. Cohn, Cultures of Plague. Medical Thinking at the End of the Renaissance, Oxford 2012, s. 18-20; S. Pender, N.S. Struever, Rhetoric and Medicine in Early Modern Europe, Farnham 2012, s. 142. 
było empiryczne podejście do choroby, zapoznanie się z anatomią człowieka. Dzięki szerokiej praktyce rozwijała się też nozologia, czyli dziedzina zajmująca się klasyfikacją chorób i ich opisem. Z protestantyzmem należy łączyć również odrodzenie i rozkwit niektórych metod leczenia, zwłaszcza balneologii. Akurat w krajach protestanckich zwolennicy Paracelsusa ${ }^{8}$ zwrócili uwagę na lecznicze właściwości metali, co wymagało poznania źródeł mineralnych.

Tworzenie nowych norm funkcjonowania i ich wprowadzanie w krajach objętych reformacją spotkało się z katolicką opozycją. Była ona widoczna i w dziedzinie medycyny. W wyniku takiej konfrontacji ukształtowały się w zakresie usług medycznych dwa przeciwstawne obozy: medyków i pacjentów protestantów oraz medyków i pacjentów katolików. Zarysowany między nimi podział był bardzo wyraźny9 ${ }^{9}$ Na jego wielkość wpływał ogólny poziom tolerancji w danym kraju oraz doświadczenie życiowe konkretnych rodów. Nierzadko pacjenci wyznania katolickiego rezygnowali z usług medyków protestantów i na odwrót. Czasem odmawiano nawet korzystania $\mathrm{z}$ leków, które wynalezienie przypisywano jednemu bądź drugiemu obozowi. Uznawano to za zdradę religijną. Niekiedy dochodziło nawet do tak kuriozalnych sytuacji, że wybierano pewną śmierć zamiast kuracji. Wspomnę tylko przykład chininy - najbardziej skutecznego leku w zwalczaniu malarii. Środek ten w pierwszej połowie XVII w. przywieźli z Ameryki Południowej do Europy jezuiccy misjonarze, którzy zauważyli, że Indianie w Peru i Boliwii leczą nim gorączkę ${ }^{10}$. Dlatego specyfik ten zyskał wśród protestantów nazwę „proszku jezuitów”, „kory jezuitów” albo „wynalazku diabła”, nie wierzono $\mathrm{w}$ jego przydatność ${ }^{11}$. Łączenie medykamentu z katolickim otoczeniem utrudniało stosowanie go w medycynie, a poparcie Watykanu działało nawet odstraszająco ze względu na obawy przed papieżem ${ }^{12}$. Medycy i pacjenci protestanci nie zgadzali się na stosowanie lekarstw innowierców. W legendarnej wersji o przyczynach śmierci jednego z najwybitniejszych protestanckich polityków angielskich Olivera Cromwella (1599-1658) wskazuje się, że podczas choroby na malarię nie zgodził się na zażywanie chininy z powodów religijnych ${ }^{13}$.

Powstaje pytanie, czy tego rodzaju kontrowersje pomiędzy medykami i pacjentami protestanckimi i katolickimi występowały w Wielkim Księstwie Litewskim? Szukając na nie odpowiedzi, posłużę się przykładem lekarzy jednego

8 Przedstawiciel nowej medycyny, pochodzący ze Szwajcarii lekarz, alchemik, botanik i filozof Phillippus Aureolus Theophrastus Bombastus von Hohenheim, inaczej Paracelsus (1493-1541); M. Lindemann, Medicine and Society in Early Modern Europe, Cambridge 2010, s. 84-87.

9 C.D. Gunnoe, Thomas Erastus and the Palatinate. A Renaissance Physician in the Second Reformation, Leiden 2011, s. 221.

${ }^{10}$ P. Daszkiewicz, Drzewo chinowe - historia widziana $z$ francuskiej perspektywy, „Rocznik Polskiego Towarzystwa Dendrologicznego" 60, 2012, s. 43-46.

11 A. Saar-Kozłowska, op. cit., s. 360.

12 S. Eyal, The Fever Tree: from Malaria to Neurological Diseases, „Toxins” 10, 2018, nr 12, s. 491.

${ }^{13}$ H.F. McMains, The Death of Oliver Cromwell, Lexington 2015, s. 29-60. 
Raimonda Ragauskienè

z najwybitniejszych przedstawicieli protestantyzmu na Litwie, księcia na Ołyce i Nieświeżu, wojewody wileńskiego, kanclerza Wielkiego Księstwa Mikołaja Radziwiłła „Czarnego” (1515-1565). Omówienie sposobów udzielania usług medycznych pomoże jednocześnie ukazać związki łączące przedstawicieli tej grupy zawodowej ${ }^{14} \mathrm{z}$,wielkim heretykem” ${ }^{15}$ - jak wojewodę wileńskiego w 1553 r. nazywał nawet król niemiecki, potem święty cesarz rzymski Ferdynand I Habsburg. Informacje o medykach magnata litewskiego w źródłach nie są obfite. Dlatego wykorzystam również przekazy medyków służących nieco później u protestantów Radziwiłłów na Birżach i Dubinkach. Wspomniana gałąź Radziwiłłów, znana od końca XV w. aż do jej zaniknięcia w końcu XVII w., wyznawała protestantyzm. Nie zmienili oni wyznania nawet wtedy, gdy po zmianie sytuacji w państwie poglądy ewangelickie raczej utrudniały karierę polityczną. Z drugiej strony trzeba też zauważyć, że choć przy wyborze małżonków pierwszeństwo oddawali ewangelikom, to w tej gałęzi dominowały rodziny mieszane pod względem religijnym. Nawet swoje córki Radziwiłłowie częściej wydawali za katolików (59\%) niż za protestantów $(41 \%)^{16}$.

W rodzinie Mikołaja Radziwiłła „Czarnego” również zachodziły zmiany pod względem wyznaniowym. Żona magnata - Polka Elżbieta Szydłowiecka (1533-1562) - najmłodsza córka kanclerza koronnego i kasztelana krakowskiego Krzysztofa Szydłowieckiego i Zofii z Targowiska, była wyznania katolickiego, lecz pod wpływem męża przeszła na protestantyzm. Najprawdopodobniej nie była to jej dobrowolna decyzja, lecz podporządkowanie się woli małżonka. W jednym z listów do matki na jej zarzuty, że córka „nie bywa w kościele i nie przyjmuje ciała Chrystusa ani mszy słucha, tylko luterańskich kazań”, Elżbieta Radziwiłłowa odpowiada, że tak powinna się zachowywać, ponieważ według niej „musiałam czynić, co mi wskazano" i widząc, że innym zachowaniem sprawiłaby małżonkowi przykrość, nie odważyła się mu sprzeciwić ${ }^{17}$. Chociaż - jak sama miała wyznać

${ }^{14}$ Dotychczas niewiele wiadomo na temat lekarzy M. Radziwiłła „Czarnego”. Wśród innych klientów magnata zostali ukazani tylko dwaj jego lekarze: Jerzy i Rupert; zob. Г. Брэгер, Кліентэла віленскага ваяводы, канилера ВКЛ Мікалая Радзівіла Чорнага паводле кніг віленскага уурада 1551-1565 г2. Спісы кліентау. Выбраныя біяграмы, w: Studia Nesvisiensia, Мікалай Радзівіл Чорны палітык, дыпламат, мецэнат, t. 3, red. Л. Яцкевіч, Нясвіж 2016, s. 23, 45. Wspomniany Rupert to medyk Rupert Fink; jego biogram zob. R. Ragauskienė, Vaistininkai XVI a. Vilniuje, „Vilniaus istorijos metraštis” 1, 2007, s. 42-45.

15 D. Pociūtè, Radvilo Juodojo atsakymas nuncijui Lippomanui (1556). Lietuvos Evangeliku Bažnyčios ìkūrimo ir Reformacijos manifestas, w: Du laiškai. Popiežiaus nuncijaus Luigi Lippomano ir kunigaikščio Mikalojaus Radvilo Juodojo polemika (1556), red. D. Pociūtè, Vilnius 2015, s. 17.

16 Więcej o religijnych aspiracjach tej gałęzi rodu zob. R. Ragauskienė, Mirties nugalèti nepavyko: Biržu ir Dubingiu kunigaikščiu Radvilų biologine istorija (XV a. pab.-XVII a.), Vilnius 2017.

17 AGAD, AR, dz. IV, kop. 674, nr 8, E. Radziwiłłowa do matki Z. Szydłowieckej, Czarnowczyce, ok. 1553-1554; R. Ragauskienè, A. Ragauskas, Barboros Radvilaités laiškai Žygimantui Augustui ir kitiems. Studija apie XVI a. Lietuvos Didžiosios Kunigaikštystès moterų korespondenciją, Vilnius 2001, s. 97. 
przed śmiercią - protestantką stała $\mathrm{z}$ dobrowolnego wyboru ${ }^{18}$, na pewno nie była niechętna katolikom. Należałoby przypomnieć, że jeden z synów „Czarnego” Jerzy (1556-1600) - został kardynałem Kościoła rzymskokatolickiego.

Pomiędzy Radziwiłłami i niektórymi świadczącymi im usługi medykami zawiązywały się nie tylko układy pacjent - medyk, lecz czasami i głębsze: patron - klient. Związek z obu stron cechowała nieoficjalność, słabszy partner zobowiązywał się wiernie służyć, świadczyć różne usługi za pewne wynagrodzenie, protekcję. Opiekunowie świadczyli także inną możliwą pomoc ${ }^{19}$. System klienteli i funkcjonowanie nieformalnej struktury władzy wymagał sprzyjających warunków. Najistotniejszym elementem było to, że pewne zasoby, więzi społeczne były zmonopolizowane, a potencjalni klienci mogli z nich korzystać tylko za przyzwoleniem możnowładców, którzy wymagali osobistej odpowiedzialności ${ }^{20}$.

\section{Protestanccy lekarze Mikołaja Radziwiłła "Czarnego"}

Początkowo Radziwiłłowie korzystali z usług lekarzy królewskich lub wolno praktykujących. Od połowy XVI w. książęta nieświescy i birżańscy utrzymywali już prywatnych medyków, nadal jednak korzystając ze specjalistów królewskich i wolno praktykujących w Wielkim Księstwie. Niekiedy w tym celu udawali się także za granicę. Magnaci zapraszali medyków o najwyższych kwalifikacjach, znanych, będących absolwentami uniwersytetów. Większość z nich to byli doktorzy medycyny, sławni i w innych naukach - matematyce, astronomii, inżynierii czy nawet $w$ poezji. Nierzadko wysokie osiągnięcia $w$ innych dziedzinach lub ściślejsze więzi z magnatem wpływały na zmianę charakteru służby ${ }^{21}$. Lekarze Radziwiłłów stosowali nowatorskie, najbardziej postępowe w tych latach metody leczenia. W XVI w. byli to zarówno miejscowi medycy, jak też Polacy i Niemcy lub miejscowi pochodzenia niemieckiego. Później napotykamy także Żydów, Włochów, Francuzów. Przedstawiciele rodu aspirującego do poziomu królewskiego mogli sobie pozwolić na zatrudnianie specjalistów pracujących tylko dla królów.

${ }^{18}$ C. Bazylik, Krótkie opisanie sprawy przy śmierci i pogrzebie Oświeconej Księżny Paniej Halżbiety z Szydłowca Radziwiłłowej, wojewodzinej wileńskiej, w: S. Kot, Nieznany poeta polski XVI wieku, „Zeitschrift für slavische Philologie” 25, 1956, nr 1, s. 127-145.

19 Więcej o funkcjonowaniu systemu zob. U. Augustyniak, Dwór i klientela Krzysztofa Radziwiłła (1585-1640). Mechanizmy patronatu, Warszawa 2001.

20 Szerzej o rozumieniu i funkcjonowaniu systemu klienteli w Europie i Rzeczypospolitej wczesnonowożytnej zob. A. Mączak, Rządzacy i rządzeni. Władza i społeczeństwo w Europie wczesnonowożytnej, Warszawa 1986; idem, Klientela. Nieformalne systemy władzy w Polsce i Europie XVI-XVIII w., Warszawa 1994; idem, Nierówna przyjaźn. Układy klientalne w perspektywie historycznej, Wrocław 2003; U. Augustyniak, Specyfika patronatu magnackiego w Wielkim Księstwie Litewskim w XVII wieku. Problemy badawcze, „Kwartalnik Historyczny” 110, 2002, nr 1, s. 97-110.

${ }^{21}$ R. Ragauskiene, Mirties nugaleti nepavyko..., s. 268. 
Nie będzie przesady w stwierdzeniu, że przy wyborze lekarzy i środków medycznych Radziwiłłowie mieli do dyspozycji cały europejski rynek.

Zarówno wśród lekarzy Mikołaja Radziwiłła „Czarnego”, jak i jego rodziny z linii birżańskiej obserwujemy wyraźną dominację protestantów. Możemy wyróżnić trzy aspekty ich związków z Radziwiłłów: udzielana przez magnatów pomoc specjalistom o europejskiej sławie, wyprawy w celu odbycia kuracji do miast będących też ośrodkami protestantyzmu czy zatrudnienie protestanckich medyków we własnych dworach.

Radziwiłłowie okazali poparcie niejednemu słynnemu na Starym Kontynencie lekarzowi wyznania protestanckiego. Przykładem może być choćby doktor medycyny Johann Brettschneider, znakomitość europejskiej sławy, nazywany Placotomusem (1514-1576). Pochodził on z Frankonii, medycynę studiował na uniwersytecie w Wittenberdze, gdzie zdobył stopień doktora medycyny i zaprzyjaźnił się z Filipem Melanchtonem. W 1543 r. Marcin Luter polecił go pruskiemu księciu Albrechtowi, co umożliwiło mu uzyskanie kilkuletniej profesury na uniwersytecie w Królewcu. Jest autorem jednej z najwcześniejszych farmakopei, czyli kodeksu aptecznego (Pharmacopoea in compendium red acta, Antwerpia 1560). $\mathrm{Z}$ powodu konfliktu z medykami księcia pruskiego w $1553 \mathrm{r}$. przeniósł się do Gdańska, gdzie został miejskim lekarzem i objął patronat nad miejską apteką. Po roku został jednak oskarżony o autorstwo paszkwilu obrażającego biskupa warmińskiego Stanisława Hozjusza i wiosną 1556 r. musiał z rodziną opuścić Gdańsk. Wówczas przybył do Wielkiego Księstwa Litewskiego i przez pewien czas mieszkał w Wilnie. Do stolicy zaprosił go ówczesny wojewoda wileński Mikołaj Radziwiłł „Czarny”, którego został nadwornym lekarzem. W takim charakterze w 1558 r. wrócił do Gdańska. Nie omieszkał również odnotować tego na stronie tytułowej wydanego w tym samym roku dzieła De dieta salubri ${ }^{22}$.

Radziwiłłowie udawali się też na leczenie do protestanckich medyków działających w takich centrach reformacyjnych jak Gdańsk czy Lublin ${ }^{23}$. Oba były wyróżniającymi się ośrodkami nauk medycznych, jednocześnie słynęły z radykalnych poglądów reformacyjnych. Radziwiłłowie wspierali miejscowych medyków i utrzymywali z nimi kontakty nie tylko z powodu ich zawodowego doświadczenia. Z lubelskimi lekarzami powiązana była większość Radziwiłłów z gałęzi na Birżach i Dubinkach. U nich np. na początku XVII w. leczyła się po poronieniu księżna słucka Zofia Radziwiłłowa (1586-1612), przybywał tu także Janusz I Radziwiłł (1579-1620). W ostatnich latach życia Krzysztof II Radziwiłł (1585-1640) wynajął

22 S. Sokół, Medycyna w Gdańsku w dobie Odrodzenia, Wrocław 1960, s. 40-41; Z.H. Nowak, Placotomus, w: PSB, t. 26, Warszawa-Kraków 1981, s. 634-635.

${ }^{23}$ J. Riabinin, Lekarze w księgach miejskich lubelskich XVI-XVIII w., Lublin 1933; M. Bogucka, Health Care and Poor Relief in Danzig (Gdansk). The Sixteenth and First Half of the Seventeenth Century, w: Health Care and Poor Relief in Protestant Europe 1500-1700, red. A. Cunningham, O.P. Grell, London-New York 2003, s. 209-210. 
w charakterze lekarza arianina z Lublina Pawła Krokiera (zm. 1642 r.), który przez pewien czas był rektorem gimnazjum ariańskiego w Rakowie ${ }^{24}$. Ten sam magnat otrzymywał też porady medyczne od aktywnego protestanta $\mathrm{z}$ Lublina Samuela Makowskiego (koniec XVI w. - 1664) ${ }^{25}$. Przez kilka lat był on seniorem kalwińskiej gminy lubelskiej. W tym jednak przypadku to nie lekarz uratował życie pacjentowi, lecz wręcz odwrotnie. W 1633 r. w czasie antykalwińskiego tumultu lubelskiego zarzucono Makowskiemu zabicie ucznia kolegium jezuickiego, za co został skazany na karę śmierci. Jego obroną, z pomyślnym skutkiem, zajęli się: przywódca lubelskich protestantów Zbigniew Gorajski i właśnie Krzysztof II Radziwiłł ${ }^{26}$. Jednak kiedy w 1640 r. magnat chciał zatrudnić Makowskiego, ten odmówił, twierdząc, że jako nadworny lekarz zostawiłby bez pomocy medycznej wielu innych chorych.

Zarówno Mikołaj Radziwiłł „Czarny”, jak i Radziwiłłowie z Birż starali się zatrudniać jako osobistych lekarzy w swych dworach protestantów. Konsyliarzem "Czarnego" był pochodzący z Inflant (Rygi) medyk, protestant Joachim Zimerman (zm. po 1559 r.). Prawdopodobnie jego ojciec Antoni Zimerman za 150 zł rocznie służył na dworze Zygmunta Starego. Joachim Zimerman z braćmi otrzymał w 1550 r. przywilej nobilitacyjny cesarza Karola V - niewątpliwie za usługi medyczne. Radziwiłł „Czarny” w styczniu 1555 r. podarował mu dom w Wilnie przy ulicy św. Jana. Zimerman sprzedał go w 1559 r. klientowi magnata, Maciejowi Sawickiemu. W końcu XVI w. w Wilnie leczył inny przedstawiciel rodziny Zimermanów, również doktor medycyny, Jan, prawdopodobnie syn Joachima. Jako senior gminy kalwińskiej w 1595 r. podpisał uchwałę o skierowaniu siedmiu delegatów na synod w Toruniu, a w 1597 r. kierował zborem kalwinistów w Nowogródku ${ }^{27}$.

Wśród najsłynniejszych medyków Radziwiłła „Czarnego” z pewnością należy wymienić przybyłego na dwór litewskiego magnata i pracującego tu Giovanniego Giorgia Biandratę (Jerzego Blandratę, ok. 1516-1588). Pochodzący z Turynu Biandrata studiował medycynę na uniwersytetach w Montpellier, Padwie i Bolonii. Specjalizował się w ginekologii, w 1538 r. w Bolonii otrzymał w tej dziedzinie

${ }^{24}$ M. Bogucka, Health Care and Poor Relief in Danzig (Gdansk)..., s. 209-210; S. Tworek, Krokier (Kroker) Pawet, w: PSB, t. 15, Kraków 1970, s. 315; AGAD, AR, dz. V, kop. 328, Świadoście, Krzysztof II Radziwiłł do starosty urzędowskiego Jerzego Rzeczyckiego, 15 IX 1640 r.

25 Российская Национальная Библиотека в Санкт Петербурге, f. 971, aut. 115, nr 113, Instrukcja Krzysztofa II Radziwiłła, Wilno, 15 VI 1628 r.

26 D. Kupisz, Zbigniew Gorajski (1596-1655). Studium z dziejów szlachty protestanckiej w Małopolsce w pierwszej połowie XVII wieku, Warszawa 2000, s. 82-84.

27 Latvijas valsts vēstures arhīvs, f. 5561, nr 374, 375; AGAD, Archiwum Skarbu Koronnego, Rachunki królewskie, dz. 1, nr 149a, k. 96; Pergamentu katalogas, wyd. R. Jasas, Vilnius 1980, nr 562, s. 223; Описание рукописного отделения Виленьской публичной библиотеки, t. 3, Вильна 1898, nr 165; LMAVB, f. 1, nr 165; f. 16, nr 202, k. 118(232); S. Kośmiński, Słownik lekarzów polskich, Warszawa 1888, s. 76. 
stopień doktora, a w 1539 r. opublikował pracę dedykowaną królowej Bonie i jej córce, królowej Węgier Izabeli Jagiellonce. W 1540 r. został lekarzem Bony, a w latach 1545-1552 był konsyliarzem królowej Węgier. W 1552 r. wrócił na pewien czas do Włoch, włączył się do ruchu protestanckiego. W $1558 \mathrm{r}$. znowu przybył do Polski, a stąd udał się do Wielkiego Księstwa Litewskiego. W styczniu 1559 r. gościł u Mikołaja Radziwiłła "Czarnego". Po poznaniu słynnego ideologa protestanckiego magnat okazał mu zaufanie. Na jego zaproszenie medyk przybył do Wilna wiosną $1560 \mathrm{r}$. Spędzili razem wiele czasu, dyskutując na tematy wyznaniowe, szczególnie o różnicach w poglądach Biandraty i Kalwina. Należy przypuszczać, że Włoch rodzinę magnata również leczył. W lipcu $1561 \mathrm{r}$. „Czarny” wysłał z Wilna list do Kalwina, w którym wyraźnie stanął po stronie włoskiego medyka. Pragnąc załagodzić złość Kalwina, podarował mu nie tylko „futro tumaka”, lecz i lniany ręcznik „wykonany przez swą najdroższą małżonkę”. Ufając i broniąc swego lekarza, Radziwiłł proponował mu pozostanie na Litwie, jednakże w 1563 r. Biandrata wyruszył do Siedmiogrodu i został lekarzem na dworze Stefana Batorego ${ }^{28}$.

Z listów nuncjusza papieskiego Giovanniego Francesca Commendonego wynika, że w ostatnich dniach życia w czerwcu 1565 r. Radziwiłł „Czarny” znajdował się pod opieką kilku nieznanych bliżej lekarzy ${ }^{29}$. W Wilnie, we dworze łukiskim, próbowali oni ratować zatrutego rtęcią magnata. Jeden z nich pomyślnie zastosował leczenie rtęcią u któregoś z dworzan Radziwiłła. Sam Mikołaj, zwolennik metod Paracelsusa, uważał rtęć za właściwy środek w leczeniu wielu chorób. Jeszcze w maju 1548 r., pisząc o usunięciu z dworu kilku dworzan, którzy szkodzili w sprawie małżeństwa królewskiego, twierdził, że „to zło nie może być leczone jedynie rtęcią?" ${ }^{30}$. W 1565 r., chcąc zmniejszyć ból stawów, wileński wojewoda polecił, by wysmarowano go rtęcią. Lekarz, który wyleczył dworzanina, zdając sobie sprawę ze szkodliwości stosowania dużej ilości rtęci, nie zgadzał się na przeprowadzenie takiej kuracji. Sprzeciwili się temu pomysłowi również inni medycy, mimo to Mikołaj Radziwiłł „Czarny”, jak relacjonował nuncjusz Commendone, wysmarował trującą maścią „nie tylko stawy, lecz i głowę”. „Wzmogły się bóle, które dręczyły go przez całe trzy dni bez przerwy tak dalece, iż najprzód popękały mu oczy, uszy i gęba, następnie rozparło mu boki, a na koniec głowa rozszczepiła się na dwie części. W okropnych mękach magnat zmarł”31.

28 D. Pociūtè, Maištininkų katedros. Ankstyvoji reformacija ir lietuvių-italu evangelikų ryšiai, Vilnius 2008, s. 459-469.

${ }^{29}$ J. Jasnowski, Mikołaj Czarny Radziwiłł (1515-1565). Kanclerz i marszałek ziemski Wielkiego Księstwa Litewskiego, wojewoda wileński, Oświęcim 2015 (reprint z 1939), s. 294.

30 M. Radziwiłł „Czarny” do M. Radziwiłła „Rudego”, Masty, 18 V 1548 r., w: Listy polskie XVI wieku, t. 2: Listy z lat 1548-1550 ze zbiorów Władysława Pociechy, Witolda Taszyckiego i Adama Turasiewicza, wyd. K. Rymut, Kraków 2001, s. 21.

31 J. Jasnowski, op. cit., s. 294. 
Trudno ustalić, który z lekarzy był przy umierającym wileńskim wojewodzie. Zapewne musiał wśród nich być wieloletni lekarz rodzinny Radziwiłłów, Rupert Fink (zm. 1579 r.).

Należał on do najbardziej znanych w XVI w. specjalistów chorób oczu. Pochodzący z Prus medyk rozpoczął karierę jako aptekarz i chirurg. W Wilnie w 1552 r. nabył od aptekarza Kondrata aptekę. Na pewien czas wyjechał ze stołecznego miasta (w 1556 r. na uniwersytecie w Bolonii otrzymał stopień doktora medycyny), a powrócił w 1560 r. Zygmunt II August mianował go lekarzem swej trzeciej żony Katarzyny z Habsburgów. Fink leczył rezydującą w Wilnie królową, a także rodzinę Radziwiłłów. W czerwcu 1562 r. troszczył się o zdrowie ciężko chorej wojewodziny wileńskiej Elżbiety z Szydłowieckich Radziwiłłowej. Zmarła ona 20 czerwca tr., prawdopodobnie z powodu niewydolności serca ${ }^{32}$. Pozycja tego medyka była w omawianym okresie szczególnie mocna. Jego apteka działała prężnie, pracował w niej uczeń (aptekarczyk) Stanisław Krasnodubski, tu handlował krakowianin Łukasz, prawdopodobnie było też więcej pomocników. Fink utrzymywał w domu dwóch kucharzy, woźnicę, niemało służby. Dzięki Radziwiłłom otrzymał on majątek w Rakanciszkach ${ }^{33}$. Po śmierci Radziwiłła „Czarnego” swoje usługi zaoferował innemu wpływowemu członkowi rodu - wojewodzie wileńskiemu Mikołajowi Radziwiłłowi „Rudemu” (ok. 1515-1584). Zacieśniały się też więzi medyka z innymi klientami Radziwiłłów. Poprzez związki matrymonialne Fink zbliżył się z jednym z najsłynniejszych działaczy protestanckich na Litwie, Andrzejem Wolanem. Córka Finka Zuzanna ok. 1584 r. wyszła bowiem za mąż za Jakuba Wolana, brata Andrzeja ${ }^{34}$.

Podsumowując, protestanccy Radziwiłłowie szeroko korzystali z usług lekarzy protestantów na miejscu, jeździli na leczenie do ośrodków reformacyjnych oraz wspierali najsłynniejszych w Europie lekarzy protestantów. Nie oznacza to jednak, że szukając pomocy medycznej, odwoływali się tylko do tego środowiska.

\section{Medycy katoliccy i innych wyznań na dworze Mikołaja Radziwiłła "Czarnego"}

Radziwiłłowie doceniali potrzebę troski o zdrowie. Poświęcali temu wiele czasu i finansów, tworząc system ochrony zdrowia dla siebie i członków swojej rodziny, wypróbowywali najnowsze i uznawane za najefektywniejsze środki medyczne. Ciężka choroba w rozumieniu Radziwiłłów to nie tylko była kara Boska, lecz

\footnotetext{
${ }^{32}$ M. Karpluk, J. Pirożyński, O nieuwiarowaniu śmierci - rękopiśmienna relacja świadka ostatnich dni Elżbiety z Szydłowieckich Radziwiłłowej, „Miscellanea Staropolskie” 6, 1990, s. 65-91.

33 VUB, Rankraščių skyrius, f. 7, nr 29, k. 735; Lietuvos Metrika. Knyga nr 51 (1566-1574). Užrašymu knyga 51, wyd. A. Baliulis, R. Ragauskienè, A. Ragauskas, Vilnius 2000, s. 330-332.

34 R. Ragauskienè, Karališkojo Birštono praeitis. Istorine raida iki XIX a., Vilnius 2004, s. 65.
} 
i największe zło. Dlatego w obliczu śmiertelnego zagrożenia bez wahania zwracali się do medyków innych wyznań, jeżeli byli oni lepszymi specjalistami lub - w potrzebie - nie mieli przy sobie lekarzy protestantów. Wówczas poglądy religijne stawały się kwestią drugorzędną. Należy przypomnieć, że do czasu przejścia Mikołaja Radziwiłła „Czarnego” na protestantyzm w 1553 r., a nawet później, zdecydowana większość lekarzy magnata była katolikami. Problem polega jedynie na tym, że prawie nie mamy informacji o tym bądź są to wzmianki bez podania imienia. Wiadomo, że na początku lutego 1551 r. Radziwiłł „Czarny” wysłał do Krakowa na pomoc stryjecznej siostrze Barbarze Radziwiłłównie trzech swoich lekarzy. Niestety, nie znamy imienia żadnego z nich. Mógł wśród nich być pochodzący z Mazowsza doktor nauk medycznych, który w 1534 r. ukończył uniwersytet w Krakowie, kanonik wileński, astrolog Wojciech Grabowski z Sierpca (zm. 12 października 1570 r.) $)^{35}$.

Później, gdy Radziwiłł stał się aktywnym działaczem reformacji, na decyzję o skorzystaniu z usług lekarzy katolików wpływ miał dość wysoki poziom tolerancji religijnej w Wielkim Księstwie ${ }^{36}$. Chyba jednym z najlepszych tego przykładów jest decyzja wojewodziny wileńskiej Anny z Kiszków Radziwiłłowej o zażyciu lekarstwa przypisywanego katolikom - wspomnianej już chininy. W 1628 r. prawdopodobnie z powodu bólów w okolicy wątroby zdecydowała się zażywać chininę, a leczący ją balwierz zwrócił się do księcia Krzysztofa II z prośbą o pozwolenie na zastosowania tego środka ${ }^{37}$.

Medycy wyznania katolickiego zazwyczaj bez przeszkód leczyli protestantów, ponieważ poglądy niektórych osób nie były jeszcze wówczas wyraźnie zdeklarowane i dochodziło do częstych konwersji. Ludzie żyjący w tej epoce byli poszukiwaczami prawdy Bożej, której upatrywali w różnych konfesjach. Dotyczyło to również przedstawicieli medycyny. Dobrym przykładem takiej postawy może być lekarz Mikołaja Radziwiłła „Czarnego”, pochodzący z rodziny szlacheckiej spod Ejszyszek Jerzy Pietkiewicz (zm. 1574 r.), syn Mikołaja, który studiował medycynę w Niemczech i we Włoszech. W 1556 r. na uniwersytecie w Ferrarze otrzymał stopień doktora nauk medycznych, wrócił na Litwę i pracował jako lekarz najpierw u biskupa żmudzkiego Jana Domanowskiego, a następnie u ewangelika Radziwiłła „Czarnego". W 1561 r. został kanonikiem żmudzkim, a w 1563 r. - kanonikiem kapituły wileńskiej. Pomimo nieodpowiednich cech - niskiego pochodzenia i faktu, że był „niezbyt skłonny do trzeźwości”, w 1567 r. został biskupem żmudzkim ${ }^{38}$.

${ }^{35}$ W. Pawlikowska, Kanonik Wojciech Grabowski z Sierpca - zapomniana postać szesnastowiecznego Krakowa i Wilna, „Lituano-Slavica Posnaniensia. Studia Historica” 11, 2005, s. 165-240.

${ }^{36}$ D. Karvelis, op. cit., s. 18.

37 AGAD, AR, dz. V, nr 3016, D. Detelewes do Krzysztofa II Radziwiłła, Kojdanów, 12 V 1625 r.

38 P. Rabikauskas, Krikščioniškoji Lietuva. Istorija, hagiografija, šaltiniotyra, red. L. Jovaiša, [Vilnius] 2002, s. 155-156. 
Warto jeszcze wspomnieć o innej postaci - Kasprze Wilkowskim ze Lwowa (druga połowa XVI w. - początek XVII w.), który służył synowi Radziwiłła „Czarnego” - Mikołajowi Krzysztofowi „Sierotce”. Urodził się on w rodzinie arianina i był aktywnym działaczem reformacji. Medycynę studiował w Niemczech. W 1583 r. przeszedł jednak w Wilnie na katolicyzm i ostro atakował swoich byłych współwyznawców. Wydał w Wilnie pisma polemiczne, m.in. Przyczyny nawrócenia do wiary powszechnej od sekt nowokrzczeńców samosateńskich, uznawane za dywersję jezuicką, dążenie do skompromitowania całej społeczności ariańskiej ustami ich dawnego współwyznawcy. Wilkowski lekceważąco wypowiadał się o przedstawicielach niższych stanów, takich jak krawcy czy szewcy, uznawanych w Kościele protestanckim za równych. Krytykował kazania mające na celu pozyskanie prostego ludu, a piętnujące życie książąt. Nie na darmo radykalni protestanci zarzucali mu, że od arian odepchnęła go żądza bogactwa. W końcu XVI w. został on lekarzem katolika Radziwiłła „Sierotki”. Nie stanowiło to jednak przeszkody w świadczeniu usług także Radziwiłłom protestantom ${ }^{39}$.

Warto wskazać jeszcze jeden podobny przykład z epoki - Simona Simoniusa z Lukki (1532-1602). To chyba najczęściej omawiana we współczesnej historiografii postać medyka w szesnastowiecznej Rzeczypospolitej. Analizowane są jego publikowane prace, poglądy filozoficzne i biografia, chociaż o polskim i litewskim okresie jego życia niewiele wiadomo. Szczególnie dużo uwagi poświęcono jego kontrowersyjnym poglądom religijnym, które zmieniał kilkakrotnie, co oceniano następująco: „początkowo katolik, następnie kalwin, potem luteranin, w końcu znowu katolik, lecz zawsze ateista"40. W 1582 r. pod wpływem nuncjusza papieskiego Alberta Bolognettiego wrócił do katolicyzmu, choć według tegoż „bardzo ciężko zrozumieć, co się dzieje w jego głowie”41. Leczący władców i magnatów Simonius uważany jest za jednego z prekursorów nowoczesnej medycyny. Będąc profesorem na uniwersytecie w Lipsku, poznał studiujących tam przez dwa lata od lutego 1571 r. synów Mikołaja Radziwiłła "Czarnego": Jerzego, Albrechta i Stanisława, a także inne pobierające w tym czasie nauki dzieci magnatów litewskich. Z przyjemnością zajął się nauczaniem młodych Radziwiłłów, a w listach do ich brata Mikołaja Krzysztofa „Sierotki” chwalił postępy młodzieńców w nauce ${ }^{42}$. Znajomość z Radziwiłłami przyczyniła się zapewne do

39 S. Tworek, Zbór lubelski i jego rola w ruchu ariańskim w Polsce w latach 1570-1598, „Annales Universitatis Mariae Curie-Skłodowska. Sectio F, Nauki Filozoficzne i Humanistyczne" 10, 1955, s. 27-31; T. Kempa, Mikołaj Krzysztof Radziwiłt Sierotka (1549-1616), wojewoda wileński, Warszawa 2000, s. 205-206; M. Hanusiewicz-Lavallee, „Rozum mój w poimanie wezmę”. Sceptycyzm fideistyczny w świadectwie konwersji Kaspra Wilkowskiego, „Pamiętnik Literacki” 59, 2018, nr 4, s. 97-110.

${ }^{40}$ C.D. Gunnoe, op. cit., s. 221.

${ }^{41}$ L. Szczucki, Simoni (Simonius) Simone, w: PSB, t. 37, Warszawa-Kraków 1996-1997, s. 529-532.

42 BN, rkps 3276, S. Simoniusz do M.K. Radziwiłła „Sierotki”, Lipsk, 7 XII 1571 r., k. 300-300v; M. Chachaj, Zagraniczna edukacja Radziwiłłów od początku XVI do połowy XVII wieku, Lublin 1995, s. 24, 109. 
dalszej kariery Simoniusa, który został zaangażowany jako lekarz królewski na dworze Stefana Batorego, gdzie powrócił do katolicyzmu, a w marcu $1584 \mathrm{r}$. w Wilnie uczestniczył w dyspucie organizowanej przez jezuitów w kwestii wyznania. W stolicy Wielkiego Księstwa w 1584 r. zostały wydane jego pierwsze książki: De vi quinque amygdalarum in ebrietate retardanda (O mocy pięciu migdałów wstrzymujących pijaństwo) i polemika z lekarzem Camillomarcello Squarcialupo: pt. Commentariola medica et physica ad aliquot scripta, cuiusdam Camillomarcelli Squarcialupi Plumbinensis, nunc medicum agentis in Transilvania (Komentarze $z$ medycyny i nauk przyrodniczych $)^{43}$.

Ponadto, szczególnie w pierwszej połowie XVI w., w Wielkim Księstwie Litewskim wciąż odczuwano brak dyplomowanych i wykwalifikowanych specjalistów. Nawet Radziwiłłowie nie zawsze mogli zatrudnić pożądanych lekarzy. Łatwiej było z personelem medycznym średniego szczebla - cyrulikami, wśród których dominowali protestanci. W pierwszej połowie XVII w. wielu luteranów było też w cechu chirurgów. Dlatego magnaci katoliccy mieli problemy, chcąc wynająć cyrulików własnego wyznania. Według umowy z 1628 r. (potwierdzonej w 1632 i 1641 r.) przedstawiciele katolickiego duchowieństwa w Wilnie zobowiązali się przyjąć do cechu czterech mistrzów katolików, aby księża oraz katolicy miejscowi i przybysze mogli korzystać z usług mistrzów tegoż wyznania ${ }^{44}$. W 1559 r. propozycji objęcia stanowiska osobistego lekarza Mikołaja Radziwiłła „Czarnego” nie przyjął pochodzący ze Szwajcarii Anton Schneeberger (1530-1581), jeden z najsłynniejszych botaników i medyków swoich czasów. Chociaż początkowo 29-letni lekarz był gotów przyjąć tę propozycję i nawet wiosną tego roku odwiedził Wilno - chciał bowiem poznać warunki przyszłej pracy i miejsce zamieszkania, ostatecznie postanowił jednak wrócić do Krakowa, gdzie był już zadomowiony. Swoją decyzję motywował tym, że pragnie zachować niezależność: „Trudno mi to przyjąć, gdyż myślę, że sławniej jest żyć wolnym, zachować niepodległą duszę, niż w bogactwie im służyć" 45 .

Dlatego w przypadkach zatrudniania lekarzy fachowość przeważała nad kwestiami wyznaniowymi. Z tego samego powodu korzystano też z usług lekarzy Żydów. Od początku rozwoju medycyny nowożytnej Żydzi, przede wszystkim

43 C. Madonia, Simone Simoni da Lucca, „Rinascimento” 20, 1980, s. 161-197; idem, Il soggiorno di Simone Simoni in Polonia, „Studi e ricerche II” 1983, s. 275-295; J. Tedeschi, The Cultural Contributions of Italian Protestant Reformers in the Late Renaissance, w: Libri, Idee e Sentimenti religiosi nel Cinquecento, red. A. Prosperi, A. Biondo, Modena 1987, s. 87-88; M. Verdigi, Simone Simoni: filosofo e medico nel '500, Lucca 1997; V. Nutton, „It's the Patient's Fault”. Simone Simoni and the Plague of Leipzig, 1575, „Intellectual History Review” 18, 2008, nr 1, s. 5-13.

${ }^{44}$ Akty cechów wileńskich 1495-1759, przyg. H. Łowmiański, M. Łowmiańska, S. Kościałkowski, red. J. Jurkiewicz, Poznań 2006, s. 221-222.

${ }^{45}$ S. Ilnicki, Wstęp, w: A. Schneeberger, De bona militum valetudine conservanda liber / Ksiega o zachowaniu dobrego zdrowia żotnierzy, tłum. i wyd. R.A. Sucharski, przyp. S. Ilnicki, R.A. Sucharski, wstęp, indeksy i red. S. Ilnicki, Warszawa 2008, s. IX. 
z powodu zdolności lingwistycznych i korzystania z dokonanych przekładów antycznych dzieł w dziedzinie medycyny, słynęli w Europie jako szczególnie dobrzy lekarze. Nie zważając na religijne czy teologiczne przekonania, czy nawet zakazy i wrogość wobec Żydów, władcy europejscy chętnie zapraszali na swoje dwory najsłynniejszych żydowskich medyków ${ }^{46}$.

Podobnie postępowali i magnaci litewscy. U Radziwiłłów w Birżach widzimy najsłynniejszych żydowskich doktorów. U Krzysztofa II praktykował Joseph Solomon Delmedigo (znany również jako Joseph Sholomon Rofe, akronim YashaR lub doktor Józef Salamon, 1591-1655) czy pochodzący z Bawarii Zachariusz Geizcofler (1560-1617) ${ }^{47}$ oraz wielu innych. „Czarny” korzystał z kolei z usług lekarza Żyda brzeskiego Mordechaja Igudicza oraz balwierzy pochodzenia niemieckiego Bartosza Mejera i Żyda Jerzego Izanaka (sic!, w ML: Юрий Изанак) ${ }^{48}$. Mejer w 1567 r. otrzymał od Zygmunta Augusta przywilej zwalniający go z obowiązku stanowienia gości w swojej kamienicy na ul. Zamkowej. Z biegiem czasu wilnianie zaczęli nazywać ją „domem Mejera”. Izanak jeszcze w 1562 r. miał ten obowiązek. Jeden z goszczących u niego, gdańszczanin Bernat Olsztyn, zadłużył się u Izanaka na 14 kop groszy. Proces balwierza z nim ukazuje związki tego medyka z wileńskim aptekarzem Janem Pigułką ${ }^{49}$.

Nie mniej istotny był dość szczególny model funkcjonowania rodu Radziwiłłów. Jak już wspomniano, żona Mikołaja Radziwiłła „Czarnego” pochodziła z katolickiego rodu Szydłowieckich. Niektóre rodziny Radziwiłłów birżańskich pod względem religijnym były mieszane. Dlatego uwzględniając życzenia żon, zapraszano lekarzy katolików, a być może i prawosławnych. Można podać przykład wspomnianego już wileńskiego kanonika Wojciecha Grabowskiego, leczącego "Czarnego" 50 . Z kolei Elżbietę Ostrogską Radziwiłłową w 1598 r. leczył doktor wileńskiej kapituły. Lekarzem Krzysztofa Mikołaja Radziwiłła „Pioruna” i jego czwartej żony był Ignacy Mamonicz, były medyk kijowskiego wojewody Wasyla Ostrogskiego. Możliwe, że był on prawosławny. Ważne było i to, że według ukształtowanej tradycji świadczenia usług medycznych możnowładcy wynajmujący konsyliarzy z powodu braku wystarczającej liczby odpowiednich specjalistów byli skłonni wymieniać się między sobą ich usługami, polecając lekarzy, którzy im pomogli, władcom, członkom rodziny, nawet innego wyznania (nieświescy birżańskim lub na odwrót), przyjaciołom. Osobisty lekarz zazwyczaj świadczył usługi dla dwóch-trzech możnowładców, a także innych zamożnych

\footnotetext{
46 E. Geller, Wprowadzenie, w: Przewodnik po drzewie żywota. O sposobie zachowania dobrego zdrowia $w$ języku jidysz przez anonimowego żydowskiego doktora $w$ Polsce w roku 1613 drukiem ogłoszony, tłum., wprow. i red. E. Geller, Warszawa 2015, s. 41-44.

47 R. Ragauskienè, Mirties nugaleti nepavyko..., s. 327.

${ }_{48}$ ML, ks. 253, k. 233-233; R. Ragauskienè, Vaistininkai XVI a. Vilniuje..., s. 42-43.

${ }^{49}$ ML, ks. 262, k. 6v.

50 W. Pawlikowska, op. cit.
} 
osób. Tak było w chociażby przypadku Macieja Vorbeka-Lettowa, który służył nie tylko Krzysztofowi II Radziwiłłowi, ale też marszałkowi wielkiemu litewskiemu Aleksandrowi Ludwikowi Radziwiłłowi (1594-1654) i kasztelanowi wileńskiemu Albrychtowi Władysławowi Radziwiłłowi (1589-1636).

Podsumowując, możemy stwierdzić, że chociaż w otoczeniu Mikołaja Radziwiłła „Czarnego” czy kręgu birżańskiej, ewangelicko-reformowanej linii Radziwiłłów widać preferencje do wybierania lekarzy protestantów, to korzystano też z usług medyków innych wyznań. W skomplikowanym pod względem konfesyjnym okresie drugiej połowy XVI i XVII w. w Wielkim Księstwie Litewskim w dziedzinie usług medycznych dużą rolę odgrywał brak fachowych lekarzy, szczególnie poszukiwano specjalistów o najwyższej kwalifikacji. Duży wpływ miała ukształtowana tradycja zatrudniania fachowych medyków, system protekcji, a szczególnie specyficzny model rodzinny Radziwiłłów oraz niemała liczba małżeństw mieszanych pod względem wyznania.

\section{Streszczenie}

W artykule przedstawiono grupę lekarzy służących najwybitniejszym protestantom w Wielkim Księstwie Litewskim - księciu na Ołyce i Nieświeżu, wojewodzie wileńskiemu Mikołajowi Radziwiłłowi „Czarnemu” (1515-1565) oraz linii Radziwiłłów na Birżach i Dubinkach. Analizy ukazały dominację w tym środowisku medyków protestantów. Radziwiłłowie szeroko korzystali z usług lekarzy protestantów na miejscu, udawali się na leczenie do takowych działających w prężnych ośrodkach protestanckich (Gdańsku czy Lublinie), a także wspierali słynnych lekarzy protestantów praktykujących w Europie. Ponieważ w Wielkim Księstwie Litewskim szczególnie w XVI w. odczuwano brak dyplomowanych i wykwalifikowanych specjalistów, magnaci bez wahania zwracali się do medyków innych wyznań, jeżeli ci byli lepszymi specjalistami lub gdy nie mieli przy sobie lekarzy protestantów. Wówczas poglądy religijne stawały się kwestią drugorzędną, dlatego korzystano z usług lekarzy katolików, prawosławnych czy Żydów. W artykule ustalono, że wszyscy medycy leczący Radziwiłłów byli specjalistami o najwyższych kwalifikacjach. Duży wpływ na wybieranie przez Radziwiłłów lekarzy protestantów miała ukształtowana tradycja zatrudniania fachowców, system protekcji oraz model rodzinny (niemała liczba małżeństw mieszanych pod względem wyznania).

\section{When Religious Views Become Irrelevant. The Physicians of the Protestants - Mikołaj the Black Radziwiłł (1515-1565) and the Biržai-Dubingiai Line of the Radziwiłł Family Summary}

The article analyses the group of physicians who served the most prominent Protestants in the Grand Duchy of Lithuania - Prince of Olyka and Nesvizh (Polish: Olyka i Nieśwież) Mikołaj the Black Radziwiłł, who was also a Voivode of Vilnius, and the Biržai-Dubingiai (Polish: 
Birże-Dubinki) line of the Radziwiłł family. The analysis of this group of professionals showed the dominance of Protestant denomination among them. The Radziwiłłs employed more willingly Protestant physicians at their court, and were more willing to go to the centers of Protestantism (Gdańsk or Lublin) for treatment. In addition, they supported the famous European Protestant physicians of their time. Nevertheless, faced with the fact that in the GDL, especially in the sixteenth century, there was a lack of qualified specialists, magnates did not hesitate to approach medics of another faith if they were indeed better specialists or if there were no Protestant physicians close at hand. When in need, religious views were no longer of importance, and Catholic, Orthodox or Jewish doctors were employed. All physicians treating the members of the Protestant Radziwiłł family were the professionals of the highest caliber. The article concludes that both the tradition of employing professional physicians, the system of protection, and especially the family model (a considerable number of mixed marriages in terms of religion) had a great impact on the selection of the Protestant physicians of the Radziwiłłs.

\section{Bibliografia}

\section{Źródła rękopiśmienne}

Archiwum Główne Akt Dawnych w Warszawie (AGAD), Archiwum Warszawskie Radziwiłłów (AR), dz. IV, kop. 674, nr 8; dz. V, kop. 328, nr 3016; Archiwum Skarbu Koronnego, Rachunki królewskie, dz. 1, nr 149a.

Biblioteka Narodowa w Warszawie (BN), rkps 3276.

Latvijas valsts vēstures arhīvs, f. 5561, nr 374, 375.

Lietuvos mokslų akademijos Vrublevskių biblioteka (LMAVB), Rankraščiu skyrius, f. 1, nr 165; f. 16, nr 202.

Metryka Litewska (ML), ks. 253, 262.

Vilniaus universiteto biblioteka (VUB), Rankraščių skyrius, f. 7, nr 29.

Российская Национальная Библиотека в Санкт Петербурге, f. 971, aut. 115, nr 113.

\section{Źródła drukowane}

Akty cechów wileńskich 1495-1759, przyg. H. Łowmiański, M. Łowmiańska, S. Kościałkowski, red. J. Jurkiewicz, Poznań 2006.

Bazylik C., Krótkie opisanie sprawy przy śmierci i pogrzebie Oświeconej Księżny Paniej Halżbiety z Szydłowca Radziwiłłowej, wojewodzinej wileńskiej, w: S. Kot, Nieznany poeta polski XVI wieku, „Zeitschrift für slavische Philologie” 25, 1956, nr 1, s. 127-145.

Lietuvos Metrika. Knyga nr 51 (1566-1574). Užrašymų knyga 51, wyd. A. Baliulis, R. Ragauskiené, A. Ragauskas, Vilnius 2000.

Listy polskie XVI wieku, t. 2: Listy z lat 1548-1550 ze zbiorów Władysława Pociechy, Witolda Taszyckiego i Adama Turasiewicza, wyd. K. Rymut, Kraków 2001.

Pergamentų katalogas, wyd. R. Jasas, Vilnius 1980.

Описание рукописного отделения Виленьской публичной библиотеки, t. 3, Вильна 1898 / Оріsanie rukopisnogo otdeleniîa Vilen'skǒ̌ publichnol̆ biblioteki, t. 3, Vil'na 1898. 


\section{Opracowania}

Augustyniak U., Dwór i klientela Krzysztofa Radziwiłła (1585-1640). Mechanizmy patronatu, Warszawa 2001.

Augustyniak U., Specyfika patronatu magnackiego w Wielkim Księstwie Litewskim w XVII wieku. Problemy badawcze, „Kwartalnik Historyczny” 110, 2002, nr 1, s. 97-110.

Bogucka M., Health Care and Poor Relief in Danzig (Gdansk). The Sixteenth and First Half of the Seventeenth Century, w: Health Care and Poor Relief in Protestant Europe 1500-1700, red. A. Cunningham, O.P. Grell, London-New York 2003, s. 204-219.

Bogucka M., Polski renesans a rodzina. Poglądy Mikołaja Reja na małżeństwo i rodzinę, w: Społeczeństwo staropolskie. Seria nowa, t. 3: Społeczeństwo a rodzina, red. I.M. Dacka-Gorzyńska, A. Karpiński, Warszawa 2009, s. 16-20.

Chachaj M., Zagraniczna edukacja Radziwiłłów od początku XVI do połowy XVII wieku, Lublin 1995.

Daszkiewicz P., Drzewo chinowe - historia widziana $z$ francuskiej perspektywy, „Rocznik Polskiego Towarzystwa Dendrologicznego" 60, 2012, s. 43-48.

Eyal S., The Fever Tree: from Malaria to Neurological Diseases, „Toxins” 10, 2018, nr 12, s. 490-499.

Geller E., Wprowadzenie, w: Przewodnik po drzewie żywota. O sposobie zachowania dobrego zdrowia $w$ języku jidysz przez anonimowego żydowskiego doktora $w$ Polsce $w$ roku 1613 drukiem ogłoszony, tłum., wprow. i red. E. Geller, Warszawa 2015, s. 41-44.

Gunnoe C.D., Thomas Erastus and the Palatinate. A Renaissance Physician in the Second Reformation, Leiden 2011.

Hanusiewicz-Lavallee M., „Rozum mój w poimanie wezmę”. Sceptycyzm fideistyczny w świadectwie konwersji Kaspra Wilkowskiego, „Pamiętnik Literacki” 59, 2018, nr 4, s. 97-110.

Ilnicki S., Wstęp, w: A. Schneeberger, De bona militum valetudine conservanda liber / Księga o zachowaniu dobrego zdrowia żotnierzy, tłum. i wyd. R.A. Sucharski, przyp. S. Ilnicki, R.A. Sucharski, wstęp, indeksy i red. S. Ilnicki, Warszawa 2008.

Jasnowski J., Mikołaj Czarny Radziwiłł (1515-1565). Kanclerz i marszałek ziemski Wielkiego Księstwa Litewskiego, wojewoda wileński, Oświęcim 2015 (reprint z 1939).

Jütte R., Contraception. A History, Cambridge 2008.

Karpluk M., Pirożyński J., O nieuwiarowaniu śmierci - rękopiśmienna relacja świadka ostatnich dni Elżbiety z Szydłowieckich Radziwiłłowej, „Miscellanea Staropolskie” 6, 1990, s. 65-91.

Karvelis D., Religijos tolerancija Lietuvos Didžiosios Kunigaikštystès tikejjimo disputu epochoje XVI-XVII a., w: Disputai: idejos, vizijos. Skiriama Reformacijos 500 metu jubiliejui, red. A. Arlauskienè, A. Prašmantaite, Vilnius 2017, s. 3-8.

Kempa T., Mikołaj Krzysztof Radziwiłł Sierotka (1549-1616), wojewoda wileński, Warszawa 2000.

Kośmiński S., Słownik lekarzów polskich, Warszawa 1888.

Kupisz D., Zbigniew Gorajski (1596-1655). Studium z dziejów szlachty protestanckiej w Małopolsce w pierwszej połowie XVII wieku, Warszawa 2000.

Lindemann M., Medicine and Society in Early Modern Europe, Cambridge 2010.

Maclean I., Logic, Signs and Nature in the Renaissance. The Case of Learned Medicine, Cambridge 2002.

Madonia C., Simone Simoni da Lucca, „Rinascimento” 20, 1980, s. 161-197.

Madonia C., Il soggiorno di Simone Simoni in Polonia, „Studi e ricerche II” 1983, s. 275-295.

Mączak A., Klientela. Nieformalne systemy władzy w Polsce i Europie XVI-XVIII w., Warszawa 1994.

Mączak A., Nierówna przyjaźń. Układy klientalne w perspektywie historycznej, Wrocław 2003.

Mączak A., Rządzący i rządzeni. Władza i społeczeństwo w Europie wczesnonowożytnej, Warszawa 1986.

McMains H.F., The Death of Oliver Cromwell, Lexington 2015.

Nowak Z.H., Placotomus, w: PSB, t. 26, Warszawa-Kraków 1981, s. 634-635. 
Nutton V., „It's the Patient's Fault”. Simone Simoni and the Plague of Leipzig, 1575, „Intellectual History Review" 18, 2008, nr 1, s. 5-13.

Pawlikowska W., Kanonik Wojciech Grabowski z Sierpca - zapomniana postać szesnastowiecznego Krakowa i Wilna, „Lituano-Slavica Posnaniensia. Studia Historica” 11, 2005, s. 165-240.

Pender S., Struever N.S., Rhetoric and Medicine in Early Modern Europe, Farnham 2012.

Pociūtė D., Maištininkų katedros. Ankstyvoji reformacija ir lietuvių-italų evangeliku ryšiai, Vilnius 2008.

Pociūtė D., Radvilo Juodojo atsakymas nuncijui Lippomanui (1556). Lietuvos Evangelikų Bažnyčios įūrimo ir Reformacijos manifestas, w: Du laiškai. Popiežiaus nuncijaus Luigi Lippomano ir kunigaikščio Mikalojaus Radvilo Juodojo polemika (1556), red. D. Pociūtè, Vilnius 2015, s. 11-56.

Rabikauskas P., Krikščioniškoji Lietuva. Istorija, hagiografija, šaltiniotyra, red. L. Jovaiša, [Vilnius] 2002.

Ragauskienè R., Karališkojo Birštono praeitis. Istorinè raida iki XIX a., Vilnius 2004.

Ragauskienè R., Mirties nugalèti nepavyko: Biržu ir Dubingių kunigaikščių Radvilų biologinè istorija (XV a. pab.-XVII a.), Vilnius 2017.

Ragauskienè R., Vaistininkai XVI a. Vilniuje, „Vilniaus istorijos metraštis” 1, 2007, s. 42-45.

Ragauskienė R., Ragauskas A., Barboros Radvilaitès laiškai Žygimantui Augustui ir kitiems. Studija apie XVI a. Lietuvos Didžiosios Kunigaikštystès moterų korespondenciją, Vilnius 2001.

Riabinin J., Lekarze w księgach miejskich lubelskich XVI-XVIII w., Lublin 1933.

Saar-Kozłowska A., Lekarz miejski Leszna Jan Jonston i kora chinowca - między religia, tradycja a medycyną, w: Reformacja i tolerancja. Jedność w różnorodności? Wspótistnienie rożnych wyznań na ziemi wschowskiej i pograniczu wielkopolsko-ślaskim, red. M. Małkus, K. Szymańska, Wschowa-Leszno 2015, s. 364-372.

Schmitt C.B., Aristotle among the Physicians, w: The Medical Renaissance of the Sixteenth Century, red. A. Wear, R.K. French, I.M. Lonie, Cambridge 1985, s. 9-11.

Siraisi N.G., Medieval and Renaissance Medicine: Continuity and Diversity, "Journal of History of Medicine and Allied Sciences" 41, 1986, nr 4, s. 391-394.

Sokół S., Medycyna w Gdańsku w dobie Odrodzenia, Wrocław 1960.

Szczucki L., Simoni (Simonius) Simone, w: PSB, t. 37, Warszawa-Kraków 1996-1997, s. 529-532.

Tedeschi J., The Cultural Contributions of Italian Protestant Reformers in the Late Renaissance, w: Libri, Idee e Sentimenti religiosi nel Cinquecento, red. A. Prosperi, A. Biondo, Modena 1987, s. 81-108.

Tworek S., Krokier (Kroker) Paweł, w: PSB, t. 15, Kraków 1970, s. 315.

Tworek S., Zbór lubelski i jego rola $w$ ruchu ariańskim w Polsce $w$ latach 1570-1598, „Annales Universitatis Mariae Curie-Skłodowska. Sectio F, Nauki Filozoficzne i Humanistyczne” 10, 1955, s. $21-48$

Verdigi M., Simone Simoni: filosofo e medico nel '500, Lucca 1997.

Wiebracht B., First-cousin Marriage in Tudor and Stuart England: 1540-1688, „Journal of Family History" 40, 2015, nr 1, s. 24-38.

Witte J., Clandestine Marriage and Parental Consent in John Calvin's Geneva, w: Law and Marriage in Medieval and Early Modern Times, red. P. Andersen, K. Salonen, H. Moller Sigh, H. Vogt, Copenhagen 2012, s. 273-298.

Брэгер Г., Кліентэла віленскага ваяводы, канилера ВКЛ Мікалая Радзівіла Чорнага паводле кніг віленскага уурада 1551-1565 гг. Спісы кліентаў. Выбраныя біяграмы, w: Studia Nesvisiensia, Мікалай Радзівіл Чорны палітык, дыпламат, меиэнат, t. 3, red. Л. Яцкевіч, Нясвіж 2016, s. 23-45 / Brèher H., Klientèla vilenskaho vaî́vody, kantslera VKL Mikolẫa Radzivila Chornaho pavodle knih vilenskaho ǔrada 1551-1565 hh. Spisy klientaǔ. Vybranyia biīahramy, w: Studia Niesvisiensia. Mikolaĭ Radzivil Chprny palityk, dyplamat, metsènat, t. 3, red. L. Tackevich, Niâsvizh 2016, s. 23-45. 
Raimonda Ragauskienè - dr, profesor, starsza badaczka w Instytucie Historii Litwy. Zainteresowania naukowe: dzieje Radziwiłłów na Birżach i Dubinkach, historia społeczna i lokalna, Metryka Litewska (publikacja i badania). Autorka książek: $1645 \mathrm{~m}$. Juzefo Naronovičiaus-Naronskio Biržu kunigaikštystès žemèlapis. Radvilu valdos istorija ir kartografija (z D. Karvelisem), Vilnius 1997; Barbora Radvilaité, Vilnius 1999; Barboros Radvilaitès laiškai Žygimantui Augustui ir kitiems. Studija apie XVI a. Lietuvos Didžiosios Kunigaikštystés moteru korespondenciją (z A. Ragauskasem), Vilnius 2001; Lietuvos Didžiosios Kunigaikštystès kancleris Mikalojus Radvila Rudasis (apie 1515-1584), Vilnius 2002; Karališkojo Birštono praeitis. Istorinè raida iki XIX a., Vilnius 2004; Iš Radvilu giminès istorijos. Dubingiu kunigaikštystė 1547-1808 m. Mokslinè monografija (z D. Karvelisem), Vilnius 2009; Dingę istorijoje: XVI a. Lietuvos Didžiosios Kunigaikštystès bajorijos privatūs archyvai, Vilnius 2015; Mirties nugalèti nepavyko. Biržų ir Dubingiu kunigaikščiu Radvilu biologiné istorija (XV a. pabaiga - XVII a.), Vilnius 2017. E-mail: raimondrag@gmail.com 